Research Article

\title{
Moderate-Severe Endometriosis Shows Higher CA-125 Serum Level Compared to Minimal-Mild Endometriosis
}

\author{
Endometriosis Sedang-Berat Menunjukkan Kadar CA-124 Serum
}

Sandhy Prayudhana, Jhonny Yudho, Wachyu Hadisaputra

Department of Obstetrics and Gynecology

Faculty of Medicine University of Indonesia/

Dr. Cipto Mangunkusumo National General Hospital

Jakarta

\begin{abstract}
Objective: To investigate and compare serum profile of CA-125, erythrocyte sedimentation rate (ESR) and C-reactive protein (CRP) in various stages of endometriosis.

Methods: Forty endometriosis patients' blood samples were taken prior to laparoscopic surgery for various indications. Diagnosis of endometriosis was confirmed by laparoscopy. Independent $\mathrm{T}$ test methods were used for statistical analysis. ROC analysis was examined for each variable.

Results: The mean level of CA- 125 serum was 12.0 vs. $36.3 \mathrm{U} / \mathrm{ml}$ (p $<0.05$ ); ESR serum was 11 vs. $12.8 \mathrm{~mm} /$ hour ( $>$ > 0.05); CRP serum was 0.7 vs. $0.3(\mathrm{p}>0.05)$ for endometriosis stage I-II and stage III-IV, respectively. The optimal cut off point to discriminate endometriosis stage I-II and III-IV was $16.9 \mathrm{U} / \mathrm{ml}$ with sensitivity $83 \%$ and specificity $81 \%$.

Conclusion: The CA-125 serum level was increased for moderatesevere endometriosis compare to minimal mild endometriosis patient.

[Indones J Obstet Gynecol 2012; 36-3: 121-4]

Keyword: CA-125, CRP, endometriosis, ESR, serum
\end{abstract}

Abstrak

Tujuan: Mengetahui dan membandingkan profil serum CA-125, Laju endap darah (LED) dan C-reactive protein (CRP) dalam berbagai stadium endometriosis.

Metode: Empat puluh pasien endometriosis diambil sampel darahnya sebelum dilakukan operasi laparoskopi. Analisis statistik menggunakan metode T tidak berpasangan. Analisis ROC diperiksa untuk setiap variabel.

Hasil: Rerata serum CA-125 12,0 U/ml dan 36,3 U/ml ( $p<0,05)$; serum LED $11 \mathrm{~mm} / \mathrm{jam}$ dan 12,8 mm/jam ( $p>0,05)$; serum CRP 0,7 dan $0,3$ ( $p>0,05)$; masing-masing untuk stadium endometriosis I-II dan III-IV. Titik potong optimal untuk membedakan endometriosis stadium I-II dengan III-IV adalah 16,9 U/ml dengan sensitivitas 83\% dan spesifisitas $81 \%$.

Kesimpulan: Terdapat perbedaan kadar serum CA-125 yang bermakna antara pasien endometriosis sedang-berat dibandingkan dengan pasien endometriosis minimal-ringan.

[Maj Obstet Ginekol Indones 2012; 36-3: 121-4]

Kata kunci: CA-125, CRP, endometriosis, LED, serum

Correspondence: Sandy Prayudhana, Johnny, Department of Obstetrics and Gynecology Faculty of Medicine University of Indonesia, Jakarta. Telephone: 081284053849 (Yudha), 08567888982 (Johnny) Email: judiojohnny@yahoo.com

\section{INTRODUCTION}

Endometriosis is a benign gynecologic disease defined as the presence of functional endometrial glands and stromal outside the uterine cavity. The symptoms could be dysmenorrhea, dyspareunia, menstrual irregularities, and infertility. ${ }^{1}$ There is also a general agreement that endometriosis is a pelvic inflammatory process with altered function of immune-related cells in the peritoneal environment.,3 Many number of studies were conducted to support this concept, in peritoneal fluid there were increased number of activated macrophages that secrete various cytokines. ${ }^{2}$

The various cytokines were suggested involved in the mechanism of progression and associated in- fertility. ${ }^{4}$ Recently, it was reported that the level of various cytokines is also increased in the serum of patient with endometriosis even though there are still debates from the conflicting result of the studies. ${ }^{5}$ From this finding, there was suggestion that endometriosis is related to systemic subclinical inflammation. Furthermore, we questioned whether those changes are significant enough to be used as non-invasive diagnostic tools. ${ }^{6,7}$

There is a response from the body to inflammation, in which there is an increase in various plasma protein, fibrinogen, haptoglobin, caeruloplasmin and C-reactive protein (CRP). ${ }^{8}$ There are two methods commonly used for detecting the acute phase response-the erythrocyte sedimentation rate 
(ESR) and the more specific measurement of CRP concentration. ESR has been used since 1921, and became popular as a non-specific screening test for disease in the routine examination to all patients, especially in small laboratories and primary health clinics as it is cheap, easy to perform and does not require a power supply nor expensive equipment. ${ }^{8}$

The gold standard for the diagnosis of endometriosis is laparoscopy. ${ }^{1,6}$ The severity of diseases is categorized according to the American Fertility Society classification, which classifieds the disease into four groups that represent minimal to severe disease. The stage of endometriosis is positively correlated with the degree of subfertility, but not with the degree of pelvic pain.

Development of a noninvasive diagnostic test for endometriosis would have a ground breaking affect on patient's quality of life, on the efficacy of available treatment, and on the cost of endometriosis. 5,7 Many serum biomarkers were proposed for further study. One of the biomarker is CA-125, which have been researched for almost three decades. Serum CA-125 measurement is now a consolidated method for diagnosing this condition and almost routinely measured in endometriosis patient. However, its interpretation has posed a number of problems, particularly regarding its use in diagnosing minimal and mild endometriosis, whereas its value as a diagnostic aid in moderate-severe stages is well recognized.

The purpose of this study was to see the profile of preoperative CA-125, ESR and CRP serum values in surgically treated endometriosis patient for various indication.

\section{METHOD}

From January to April 2012, we collected 40 patients who underwent laparoscopic surgery for endometriosis at Bunda hospital and YPK hospital, Jakarta. The diagnosis was made intraoperative based on the finding of endometriosis lesion or endometrioma. Informed consent from the patients was obtained, and the ethical review board of University Indonesia approved the study. We collected the obstetric and gynecologic history and relevant medical history, clinical symptoms, preoperative serum CA-125, ESR and CRP levels. The assay CA125, ESR and CRP levels were performed at least 1 day before surgery. The serum CA-125 was measured by chemiluminescent immunoassay by advia centaur; serum CRP was measured by immunoturbidimetrybycobasintegra; while ESR was measured manually with SRS 20 . We used independent T test to detecting difference in mean serum CA-125, ESR and CRP. We performed receiver operating characteristic (ROC) curve analysis to assess the clinical utility of serum biomarker in distinguishing severe-moderate and minimal mild patient. The cutoff values derived from ROC curves were evaluated in terms of sensitivity and specificity.

\section{RESULT}

There were 40 subjects in this study that were classified according to the Revised American Study for Reproductive Medicine endometriosis classification. Twenty six subjects had minimal-mild and fourteen subjects had moderate-severe endometriosis. The distribution of age, BMI, and smoking in both group are similar. Minimal-mild endometriosis subjects had $88 \%$ infertility compared to $57 \%$ in moderate-severe subjects.

Table 1. Subject Characteristics

\begin{tabular}{lcc}
\hline \multicolumn{1}{c}{ Variable } & $\begin{array}{c}\text { Minimal-Mild } \\
(\mathbf{n = 2 6})\end{array}$ & $\begin{array}{c}\text { Moderate-Severe } \\
(\mathbf{n = 1 4 )}\end{array}$ \\
\hline Age (year) & 34.1 & 30.3 \\
BMI & & \\
$\quad$ Normal (18.5-24.9) & 24 & 11 \\
High ( $\geq 25)$ & 2 & 3 \\
Smoking & & \\
Yes & 2 & 2 \\
No & 24 & 12 \\
Infertility & & \\
Yes & 23 & 8 \\
No & 3 & 6 \\
Parity & & 12 \\
0 & 23 & 1 \\
1 & 2 & \\
$\geq 2$ & 1 & \\
\hline \hline
\end{tabular}

The level of serum ESR, CRP and CA-125 did not have normal distribution. We transform the data into logarithmic to have normal distribution for independent T test calculation. Serum CA-125 could discriminate endometriosis stage I-II from stage III-IV with mean level 12.0 vs. $36.3 \mathrm{U} / \mathrm{ml}$ respectively $(p=0.000)$. No difference was found for serum level ESR and CRP. 
Table 2. Bivariate analysis between ESR, CRP, and CA-125 with the severity of endometriosis.

\begin{tabular}{|c|c|c|c|c|c|c|c|}
\hline Variable & $\mathbf{G M}^{\mathrm{a}}$ & SEM & $\begin{array}{l}\mathbf{p} \text { from } \\
\Delta \text { Mean }\end{array}$ & $\begin{array}{l}\text { GM ratiob } \\
(95 \% \text { CI) }\end{array}$ & AUC & (95\% CI) & $\begin{array}{l}p \text { from } \\
\text { AUC }\end{array}$ \\
\hline \multicolumn{8}{|l|}{ ESR $(\mathrm{mm} / \mathrm{hr})$} \\
\hline Std I-II & 11.0 & 6.6 & 0.541 & $1.1(0.5-1.4)$ & 0.58 & $(0.35-0.81)$ & 0.497 \\
\hline Std III-IV & 12.8 & 5.2 & & & & & \\
\hline \multicolumn{8}{|l|}{ CRP } \\
\hline Std I-II & 0.7 & 1.3 & 0.194 & $0.4(0.6-7.3)$ & 0.29 & $(0.02-0.57)$ & 0.161 \\
\hline Std III-IV & 0.3 & 1.5 & & & & & \\
\hline \multicolumn{8}{|l|}{ CA-125 (U/ml) } \\
\hline Std I-II & 12.0 & 4.6 & 0.000 & $3.0(0.1-0.5)$ & 0.87 & $(0.74-1.00)$ & $<0.001$ \\
\hline Std III-IV & 36.3 & 1.2 & & & & & \\
\hline
\end{tabular}

${ }^{a}$ Mean was shown as Geometric Mean (GM)

${ }^{b}$ Geometric mean ratio was used to shown the difference of geometric mean
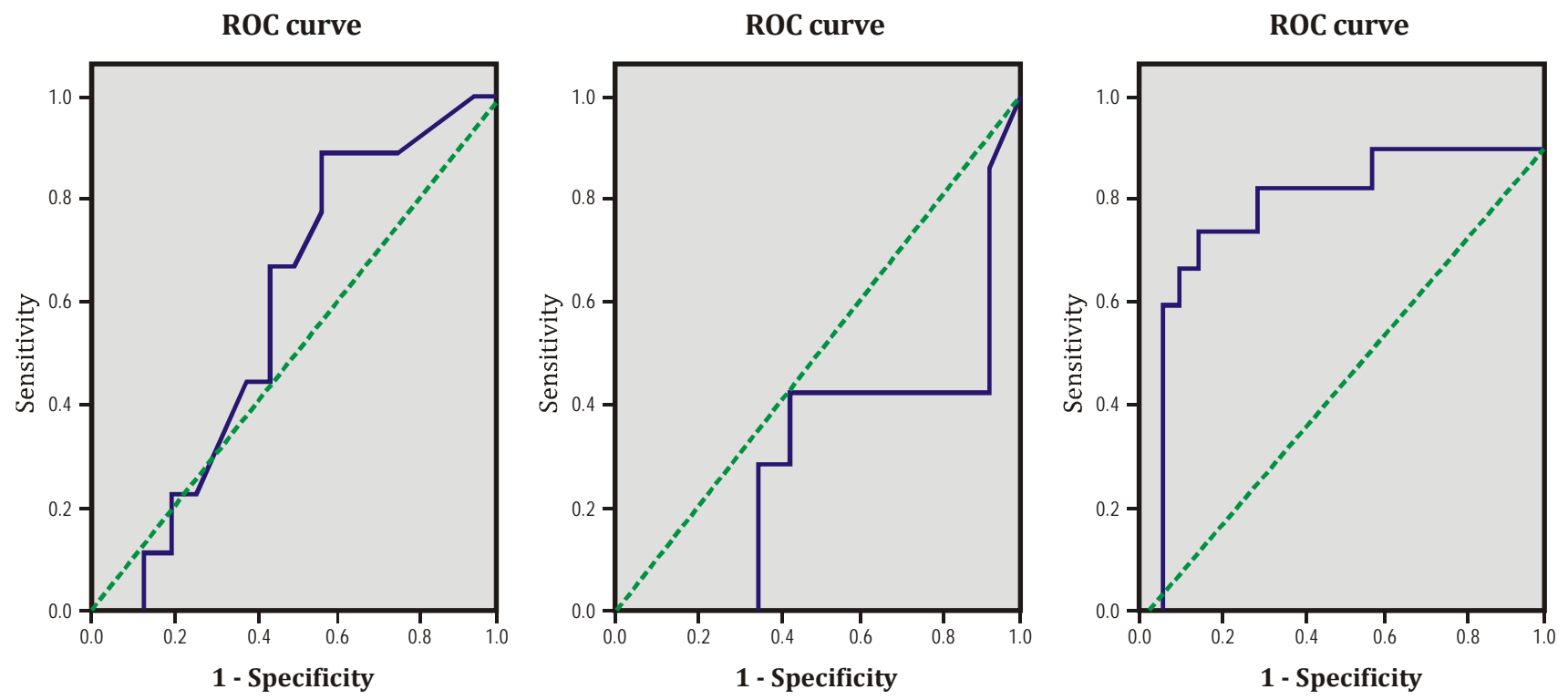

Figure 1. AUC graphic from (A) ESR, (B) CRP, and (C) CA-125 with ROC methods.

Serum CA-125 had AUC 87\% ( $p<0.001)$, meanwhile for serum ESR and CRP were 58\% ( $\mathrm{p}=$ $0.497)$ and $29 \%(p=0.161)$ respectively. From the ROC curve analysis, we acquired that the optimal cut off point for serum level CA-125 to differentiate endometriosis stage I-II and III-IV was $16.9 \mathrm{U} / \mathrm{ml}$. It has sensitivity $83 \%$ and specificity $81 \%$. If the cut off point of CA-125 was $>35 \mathrm{U} / \mathrm{ml}$, the sensitivity was $67 \%$ and specificity $90 \%$.

\section{DISCUSSION}

Women with endometriosis have been found to have elevated CA-125 levels in their serum, menstrual blood, and peritoneal fluid. However, the CA125 level is not specific to endometriosis.
This study demonstrates that preoperative CA125 assay is useful to distinguish high-risk from low-risk endometriosis patients. Our results indicate a new use for preoperative serum CA-125 examination in addition to the diagnosis of endometriosis. The results confirm previous reports that preoperative CA-125 levels increase with the stages of endometriosis. ${ }^{9}$ It further extends the observations that omentum adhesion and rupture of endometrioma are also the leading causes of elevated CA-125 levels. ${ }^{9}$ Our study acquired a sensitivity of $83 \%$ and specificity of $81 \%$ for $16.9 \mathrm{U} / \mathrm{ml}$ as the optimal cut off point for CA-125. Silva et al got a slightly different cut-off point of $20 \mathrm{U} / \mathrm{ml}$ with $44.7 \%$ sensitivity and $92.2 \%$ specificity. ${ }^{10}$ Cheng stated that CA-125 level was significantly higher in 
advanced stages. ${ }^{10}$ Furthermore, serum CA-125 levels were significantly higher in patients with more extensive adhesions of the peritoneum, omentum, ovary, fallopian tube, colon, and cul-de-sac, or with ruptured endometrioma. Several authors claimed that its combination with transvaginal ultrasonography may help the differentiation of endometrioma from other benign ovarian cysts. ${ }^{9}$ Patrelli stated that there was a relationship between the serum CA-125 values and the location of endometriosis foci, with higher elevations in ovarian and mixed forms than in extraovarian forms. ${ }^{11}$

Although the pathogenesis of endometriosis is still controversial, growing evidence indicate a significant role of inflammatory factors involved in the development of endometriosis. ${ }^{12,13}$ Biomarker such as CRP and ESR are acute phase proteins that increased when inflammation occurs. It has been suggested that in women with endometriosis there is an inflammatory reaction of the pelvic peritoneum. Inflammation, as a local response to tissue injury, results in changes of vascular caliber, flow, and increased vascular permeability. The increasing level of CRP and ESR in pelvic peritoneum due to inflammation process can also be detected in blood serum. ${ }^{12}$ However, measurement of CRP and ESR from our research did not appear to be advantageous for determining the severity of endometriosis. There was no association between CRP level and stage of the disease. Vodolazkaia reported different finding; he found statistically significant different median of CRP level between stage I-II and stage III-IV of endometriosis.

\section{CONCLUSION}

The CA-125 serum level was increased for moderate-severe endometriosis compared to minimal and mild endometriosis patient. The optimal cut off point for serum level CA-125 to differentiate bet- ween endometriosis stage I-II and III-IV is 16.9 $\mathrm{U} / \mathrm{ml}$, with $83 \%$ sensitivity and $81 \%$ specificity.

\section{REFERENCES}

1. Giudice LC. Clinical practice. Endometriosis. N Engl J Med. 2010; 362(25): 2389-98

2. Giudice LC, Kao LC. Endometriosis. Lancet 2004; 364: 178999

3. Barrier BF. Immunology of endometriosis. Clin Obstet Gynecol. 2010; 53(2): 397-402

4. Gupta S, Goldberg JM, Aziz N, Goldberg E, Krajcir N, Agarwal A. Pathogenic mechanisms in endometriosis-associated infertility. Fertil Steril. 2008; 90: 247-57

5. May KE, Conduit-Hulbert SA, Villar J, Kirtley S, Kennedy SH, Becker CM. Peripheral biomarkers of endometriosis: a systematic review. Hum Reprod Update. 2010; 16(6): 651-74

6. Hadisaputra W. Endometriosis: Tinjauan perangai imunopatobiologi sebagai modalitas baru untuk menegakkan diagnosis endometriosis tanpa visualisasi laparoskopi. Maj Obstet Ginekol Indones. 2007; 31(3): 180-4

7. Somigliana E, Vercellini P, Vigano P, Benaglia L, Crosignani PG, Fedele L. Non-invasive diagnosis of endometriosis: the goal or own goal? Hum Reprod. 2010: 1-6

8. Osei-Bimpong A, Meek JH, Lewis SM. ESR or CRP? A comparison of their clinical utility. Hematology. 2007; 12(4): 353-7

9. Cheng YM, Wang ST, Chou CY. Serum CA-125 in preoperative patients at high risk for endometriosis. Obstet Gynecol. 2002; 99(3): 375-80

10. Rosa ESAC, Rosa ESJC, Ferriani RA. Serum CA-125 in the diagnosis of endometriosis. Int J Gynecol Obstet. 2007; 96(3): 206-7

11. Patrelli TS, Berretta R, Gizzo S, Pezzuto A, Franchi L, Lukanovic A. CA-125 serum values in surgically treated endometriosis patients and its relationships with anatomic sites of endometriosis and pregnancy rate. Fertil Steril. 2011; 95(1): 393-6

12. Dunselman GA, Bouckaert PX, Evers JL. The acute phase response in endometriosis of women. J Reprod Fert. 1988; 83: 803-8

13. Vodolazkaia A, Bossuyt X, Fassbender A, Kyama CM, Meuleman C. A high sensitivity assay is more accurate than a classical assay for the measurement of plasma CRP level in endometriosis. Reprod Biol Endocrinol. 2011; 9: 113 